\title{
APPLICATION OF ECONOMIC INDICATORS TO ASSES THE BRIDGES OF REHABLITATION
}

\author{
Martin PITOŇÁK ${ }^{1, *}$, Milan VALUCH² \\ ${ }^{1}$ Centre of Excellence in Transport Engineering, Faculty of Civil Engineering, University of Žilina, \\ Univerzitná 8215/1, 01026 Žilina. \\ ${ }^{2}$ Research Centre, University of Žilina, Univerzitná 8215/1, 01026 Žilina. \\ corresponding author: martin.pitonak@fstav.uniza.sk, +421-4-1513 5898.
}

\begin{abstract}
The aim of this paper is to point out the advantage of Cost Benefit Analysis (CBA) and its economic indicators to assess a rehabilitation of bridges. The paper includes short example of assessment of the project economic efficiency in which economic indicators are applied in order to evaluate of two technology project variants of bridge object rehabilitation. It quantifies and compares the economic results of alternative 1 with the monolithic prestress construction and alternative 2, with the composite steel - concrete bridge. The contribution reflects the current practice of economic analysis recommended by the Ministry of Transport, Construction and Regional Development.
\end{abstract}

\section{Keywords:}

Economic indicator; Technological options; Project price;

Social benefits;

Generating revenues; Quality.

\section{Introduction}

At the beginning, it should be noted that only the application of economic indicators CBA method is the best possible for a comprehensive assessment of the reconstruction project effectiveness, namely the rehabilitation of bridge objects (RBO). Many technicians argue that the effectiveness of the project can be found also by its technical solution, respectively by its technical characteristics. Such an argument cannot be practically demonstrated. Moreover, it is non-complex, because it works only with technical parameters without key economic parameters, such as the acquisition cost of the project, operating costs and social benefits of the project.

\section{Particularity of assessed technological variants}

Economic evaluation is always based on a technical solution. Acquisition costs essentially reflect the cost of the technical complexity of the project and, in addition, in civil engineering also construction site conditions. The technical solution is also reflected in social benefits of the project.

Before considering the economic efficiency of the before mentioned two variants of the RBO project, it is briefly presented the reasons for rehabilitation, which are: very bad or breakdown state condition of the existing bridge object supported by extensive diagnostics, dynamic and static load test of the bridge. The present bridge structure performs services over the railway, resort of ČOV and river Kysuca. The project deals with the reconstruction of the bridge. The technical solution is designed in two variants; the variant 1 is characterized as a monolithic construction of prestressed concrete and variant 2 is characterized as a composite steel-concrete construction. The length of upperbridge is $263.400 \mathrm{~m}$, length of the bridge is 306.590 meters, the bridge span fields: $30.0+5 \times 41.0+30.0 \mathrm{~m}$, height of the bridge max. $11.92 \mathrm{~m}$ (in the field no. 6), the bridge area: $3.911 .55 \mathrm{~m}^{2}$. Alternative 1 is a cheaper to compare with alternative 2. At the same time, the alternative 1 needs more time for the realization than alternative 2 . In the long term, it can be assumed that the total operating and maintenance costs of the variant 1 will be higher about $10 \%$ compared to variant 2 . This assumption goes out from the experience of countries that have rich history in construction of composite steelconcrete bridges. An economic analysis of the project for both alternatives needs to be work out in order to make investor's decision easy which type of construction is the most suitable for him. 


\section{Inputs for decision-making process}

The decision-making process on the effectiveness of each RBO alternatives requires acquisition costs based on budgets of the two variants of bridge objects. In the next step, it is important to quantify social costs using of relevant computational model (user and environmental costs and accident rate costs). This serves in case if the reconstruction is not realized or opposite (reduced social costs). Their difference corresponds to the societal benefits of the bridge reconstruction. These benefits are reducing each year by the operating costs of reconstruction technology. For the decisionmaking process regarding the effectiveness of reconstruction, it is still necessary to know its lifetime, the terms of the project realization and the discount for the project.

\section{Application of economic indicators}

A comprehensive assessment of the economic efficiency of bridges rehabilitation projects, as it was already stated, is only possible by applying various methods of economic CBA indicators. Costbenefit analysis of the project can be carried out as an economic (if the project realization will never serve public purposes) or financial (if the building generates revenues). In our case, it is a project that will generate revenue, so we use economic analysis and the following economic indicators:

- Economic Payback Period,

- Economic Net Present Value,

- Economic Internal Rate of Return,

- Economic Benefit- Cost Ratio.

\subsection{Theoretical questions of project economic analysis}

The economic Cost Benefit Analysis is, as already mentioned, economic method, which has the economic indicators that allow assessing the economic effects of the construction project, its rate respectively. In the next section of this chapter, there are summarized in the general shape the economic indicators applied to the needs of the bridges rehabilitation projects.

\subsubsection{Economic Payback Period}

The Economic Payback Period acquisition costs for RBO can be expressed as the year in which social benefits achieved acquisition costs of RBO:

$0=\sum_{t=T z z c}^{T_{R S}} \frac{P_{t,(a-b)}-O N_{t}-P N_{t}}{(1+0,01 . u)^{t}}$,

where: $T_{z z c}$ - start of the year life cycle of technology RBO, [year],

$\mathrm{T}_{\mathrm{RS}}$ - year of repayment RBO, [year],

$\mathrm{t}=\mathrm{T}_{\mathrm{zZC}}$ to $\mathrm{T}_{\mathrm{RS}}$, [years],

$P_{t,(a-b)}$ - benefits from the implementation of the RBO, as the difference between the higher social costs of state without implementation of RBO (a) and lower social costs in state of realization $\mathrm{RBO}(\mathrm{b})$, in a year $\mathrm{t},[€]$,

$\mathrm{ON}_{\mathrm{t}}-\mathrm{RBO}$ acquisition costs in years $\mathrm{t},[€]$,

$\mathrm{PN}_{\mathrm{t}}-\mathrm{RBO}$ operating costs technology in years $\mathrm{t}[€]$,

u - discount [\%].

Economic Payback period can be expressed as a time of repayment. Thus, as a proportion of the cost of the RBO average annual societal benefits:

$T_{R S}=\frac{O N_{t}}{P_{t,(a-b), Y \text { YARaverage }}}$, 
where: $P_{t(a-b), Y E A R}$ average - average annual benefits of implementing an $R B O$, as the difference between the higher social costs in the state without the implementation of the RBO (a) and lower costs in the state where the RBO is implemented (b), between $t \in]$

\subsubsection{Economic Net Present Value}

Economic Net Present Value has an economical result in financial terms, as difference of social benefits and costs in this form:

$$
E N P V=\sum_{t=T_{Z Z C}}^{T_{U Z C}} \frac{P_{(a-b)_{t}}-O N_{t}-P N_{t}}{(1+0,01 . u)^{t}},
$$

where: ENPV - Economic Net Present Value, [€],

$\mathrm{T}_{\text {SYLC }}$ - start year life cycle RBO, [year],

$\mathrm{T}_{\mathrm{EYLC}}$ - the year of end lifecycle RBO, [year].

It applies that the effective ENPV project RBO must be non-negative.

\subsubsection{Economic Internal Rate of Return}

Economic Internal Rate of Return is the rate in which an economic net present value is equal to zero:

$$
\sum_{t=T z z c}^{T u z c} \frac{P_{t,(a-b)}-O N_{t}-P N_{t}}{(1+x)^{t}}=0,
$$

$E I R R=x .100$,

where: EIRR - Economic Internal Rate of Return, [\%], $x-$ interest rate, the search value [\%].

The basic benchmark in evaluating this economic indicator is the economic discount rate, which is usually set for the construction projects (e.g. for highway construction is currently at $5.5 \%$ ).

\subsubsection{Economic Benefit - Cost Ratio (EBCR)}

This economic indicator compares the economic net present value of all the social benefits and costs of the project life cycle and its cost of acquisition:

$$
E B C R=\frac{O N+E N P V}{O N} .
$$

\subsection{Practical calculation of economic indicators}

The following tables show the real financial flows, practical examples RMO, social and cost savings in financial terms, economic methods: Economic Payback Period - EPP, Economic Net Present Value of Investment - ENPV and Economic Internal Rate of Return - EIRR.

Economic efficiency calculations give an answer the question, to which extent is the project of the bridge's Nr. 208 rehabilitation in Čadca, according to technical and economic evaluation preferred. For the calculation takes into account all the relevant technical and economic parameters of the current and proposed technical solutions and its economic effects. 
Table 1: Flows and cost savings in financial terms, var. 1: monolithic prescription construction.

\section{Qualification of economic indicators EPP, ENPV, EIRR and EBCR}

The name of construction: I / 11 Čadca - bridge Nr. 208 variant 1: monolithic prestressed construction Brutto and Netto flow of savings and costs in financial terms, for the entire lifecycle thousand. $€$

\begin{tabular}{|l|l|l|l|}
\hline & & Brutto flow and cost savings & Netto cumulative flow of savings and costs \\
\cline { 3 - 4 } & Year & Purchase cons
\end{tabular}

\begin{tabular}{|c|c|c|c|c|c|}
\hline NR. & Year & Purchase costs & Social. benefits & $\begin{array}{c}\text { CASH FLOW } \\
\text { EIRR }\end{array}$ & $\begin{array}{c}\text { CASH FLOW } \\
\text { ENPV }\end{array}$ \\
\hline 1 & 2 & 3 & 4 & 5 & 6 \\
\hline 1 & 2015 & $5,281,080.00$ & & $4,552,563.76$ & $5,005,763.03$ \\
\hline 2 & 2016 & $5,281,080.00$ & & $8,477,108.88$ & $9,750,562.12$ \\
\hline 3 & 2017 & & $965,050.12$ & $7,858,879.36$ & $8,928,712.25$ \\
\hline 4 & 2018 & & $1,059,929.40$ & $7,273,536.80$ & $8,073,119.49$ \\
\hline 5 & 2019 & & $1,172,649.60$ & $6,715,279.12$ & $7,175,885.00$ \\
\hline 6 & 2020 & & $1,301,592.27$ & $6,181,115.01$ & $6,231,910.63$ \\
\hline 7 & 2021 & & $1,445,138.95$ & $5,669,854.04$ & $5,238,468.92$ \\
\hline 8 & 2022 & & $1,601,671.22$ & $5,181,382.02$ & $4,194,821.76$ \\
\hline 9 & 2023 & & $1,769,570.61$ & $4,716,152.24$ & $3,101,883.17$ \\
\hline 10 & 2024 & & $1,947,218.70$ & $4,274,838.31$ & $1,961,921.80$ \\
\hline 11 & 2025 & & $2,132,997.02$ & $3,858,106.70$ & $778,299.35$ \\
\hline 12 & 2026 & & $2,325,287.13$ & $3,466,476.60$ & $444,758.70$ \\
\hline 13 & 2027 & & $2,522,470.59$ & $3,100,242.41$ & $1,702,363.36$ \\
\hline 14 & 2028 & & $2,722,928.96$ & $2,759,440.22$ & $2,989,136.17$ \\
\hline 15 & 2029 & & $2,925,043.77$ & $2,443,844.05$ & $4,299,359.94$ \\
\hline 16 & 2030 & & $3,127,196.60$ & $2,152,981.48$ & $5,627,108.48$ \\
\hline 17 & 2031 & & $3,327,769.00$ & $1,886,161.04$ & $6,966,357.56$ \\
\hline 18 & 2032 & & $3,525,142.51$ & $1,642,505.71$ & $8,311,079.24$ \\
\hline 19 & 2033 & & $3,717,698.70$ & $1,420,988.90$ & $9,655,321.22$ \\
\hline 20 & 2034 & & $3,903,819.11$ & $1,220,469.92$ & $10,993,273.10$ \\
\hline 21 & 2035 & & $4,081,885.30$ & $1,039,727.58$ & $12,319,320.79$ \\
\hline 22 & 2036 & & $4,250,278.83$ & $877,490.62$ & $13,628,090.73$ \\
\hline 23 & 2037 & & $4,407,381.25$ & $732,464.47$ & $14,914,484.86$ \\
\hline 24 & 2038 & & $4,551,574.11$ & $603,354.26$ & $16,173,707.68$ \\
\hline 25 & 2039 & & $4,681,238.97$ & $488,883.90$ & $17,401,286.31$ \\
\hline 26 & 2040 & & $4,794,757.38$ & $387,811.59$ & $18,593,084.41$ \\
\hline 27 & 2041 & & $4,890,510.90$ & $298,942.02$ & $19,745,310.80$ \\
\hline 28 & 2042 & & $4,966,881.07$ & $221,135.52$ & $20,854,523.65$ \\
\hline 29 & 2043 & & $5,022,249.47$ & $153,314.60$ & $21,917,630.59$ \\
\hline 30 & 2044 & & $5,054,997.63$ & $94,468.23$ & $22,931,885.61$ \\
\hline 31 & 2045 & & $5,063,507.11$ & $43,654.23$ & $23,894,883.15$ \\
\hline 32 & 2046 & & $5,046,159.47$ & 0.00 & $24,804,549.78$ \\
\hline 33 & Total: & $10,562,160.00$ & $98,304,595.75$ & & \\
\hline \multicolumn{5}{|c|}{ Economic Payback period, [year] } & 2026 \\
\hline \multicolumn{5}{|c|}{ Economic Net Present Value of Investment, $[€]$} & $24,804,549.78$ \\
\hline \multicolumn{5}{|c|}{ Economic Internal Rate of Return, \% } & 16.00 \\
\hline \multicolumn{5}{|c|}{ Economic Benefit- Cost Ratio } & 3,348 \\
\hline
\end{tabular}

Discount: 5.5\% Year of calculation: 2014 [8] 
Table 2: Flows and cost savings in financial terms, var. 2: composite steel and concrete bridge.

Qualification of economic indicators EPP, ENPV, EIRR and EBCR

\begin{tabular}{|c|c|c|c|c|c|}
\hline \multirow{2}{*}{\multicolumn{6}{|c|}{$\begin{array}{l}\text { Qualification of economic indicators EPP, ENPV, EIRR and EBCR } \\
\text { The name of construction: I / } 11 \text { Čadca - bridge Nr. } 208 \text { variant 1: composite steel and concrete } \\
\text { bridge }\end{array}$}} \\
\hline & & & & & \\
\hline \multicolumn{6}{|c|}{ Brutto and Netto flow of savings and costs in financial terms, for the entire lifecycle thousand. $€$} \\
\hline \multirow[b]{2}{*}{ NR. } & \multirow[b]{2}{*}{ Year } & \multicolumn{2}{|c|}{ Brutto flow and cost savings } & \multicolumn{2}{|c|}{ Netto cumulative flow of savings and costs } \\
\hline & & Purchase costs & Social. benefits & $\begin{array}{c}\text { CASH FLOW } \\
\text { IRR }\end{array}$ & $\begin{array}{c}\text { CASH FLOW } \\
\text { NPV }\end{array}$ \\
\hline 1 & 2 & 3 & 4 & 5 & 6 \\
\hline 1 & 2015 & $2,872,835.00$ & & $2,473,609.61$ & $2,723,066.35$ \\
\hline 2 & 2016 & $8,223,315.00$ & & $8,570,212.12$ & $10,111,323.58$ \\
\hline 3 & 2017 & & $1,009,390.56$ & $7,925,863.85$ & $9,251,712.78$ \\
\hline 4 & 2018 & & $1,104,610.60$ & $7,318,720.68$ & $8,360,052.61$ \\
\hline 5 & 2019 & & $1,217,701.52$ & $6,742,427.83$ & $7,428,347.35$ \\
\hline 6 & 2020 & & $1,347,041.75$ & $6,193,514.32$ & $6,451,410.93$ \\
\hline 7 & 2021 & & $1,491,009.74$ & $5,670,367.22$ & $5,426,435.95$ \\
\hline 8 & 2022 & & $1,647,983.92$ & $5,172,496.27$ & $4,352,611.49$ \\
\hline 9 & 2023 & & $1,816,342.72$ & $4,700,017.73$ & $3,230,785.08$ \\
\hline 10 & 2024 & & $1,994,464.59$ & $4,253,302.15$ & $2,063,164.52$ \\
\hline 11 & 2025 & & $2,180,727.95$ & $3,832,743.34$ & $853,055.68$ \\
\hline 12 & 2026 & & $2,373,511.25$ & $3,438,615.58$ & $395,367.37$ \\
\hline 13 & 2027 & & $2,571,192.92$ & $3,070,994.12$ & $1,677,263.06$ \\
\hline 14 & 2028 & & $2,772,151.39$ & $2,729,719.79$ & $2,987,296.89$ \\
\hline 15 & 2029 & & $2,974,765.11$ & $2,414,393.75$ & $4,319,792.49$ \\
\hline 16 & 2030 & & $3,177,412.51$ & $2,124,391.59$ & $5,668,861.75$ \\
\hline 17 & 2031 & & $3,378,472.02$ & $1,858,889.20$ & $7,028,516.09$ \\
\hline 18 & 2032 & & $3,576,322.08$ & $1,616,894.86$ & $8,392,761.03$ \\
\hline 19 & 2033 & & $3,769,341.13$ & $1,397,283.65$ & $9,755,675.84$ \\
\hline 20 & 2034 & & $3,955,907.60$ & $1,198,831.55$ & $11,111,479.95$ \\
\hline 21 & 2035 & & $4,134,399.94$ & $1,020,247.57$ & $12,454,587.63$ \\
\hline 22 & 2036 & & $4,303,196.57$ & $860,202.73$ & $13,779,652.30$ \\
\hline 23 & 2037 & & $4,460,675.93$ & $717,355.56$ & $15,081,601.68$ \\
\hline 24 & 2038 & & $4,605,216.47$ & $590,373.75$ & $16,355,665.02$ \\
\hline 25 & 2039 & & $4,735,196.60$ & $477,952.11$ & $17,597,393.16$ \\
\hline 26 & 2040 & & $4,848,994.78$ & $378,826.90$ & $18,802,672.65$ \\
\hline 27 & 2041 & & $4,944,989.44$ & $291,787.03$ & $19,967,734.44$ \\
\hline 28 & 2042 & & $5,021,559.01$ & $215,682.25$ & $21,089,158.06$ \\
\hline 29 & 2043 & & $5,077,081.93$ & $149,428.87$ & $22,163,871.90$ \\
\hline 30 & 2044 & & $5,109,936.63$ & $92,013.28$ & $23,189,150.11$ \\
\hline 31 & 2045 & & $5,118,501.56$ & $42,493.63$ & $24,162,606.70$ \\
\hline 32 & 2046 & & $5,101,155.15$ & 0.00 & $25,082,187.35$ \\
\hline 33 & Total: & $11,096,150.00$ & $99,819,253.37$ & & \\
\hline \multicolumn{5}{|c|}{ Economic Payback period, [year] } & 2026 \\
\hline \multicolumn{5}{|c|}{ Economic Net Present Value of Investment, [ $€]$} & $25,082,187.35$ \\
\hline \multicolumn{5}{|c|}{ Economic Internal Rate of Return, $\%$} & 16.13 \\
\hline \multicolumn{5}{|c|}{ Economic Benefit- Cost Ratio } & 3,260 \\
\hline
\end{tabular}

Discount: 5.5\% Year of calculation: 2014 [8]

\section{Financial results}

To compare economical results variants of project RRMO, I submit recap economic indexes of individual economic indicators. 
The results of the four economic methods comprehensively and sufficiently demonstrate the economic efficiency exchangeable technological variants of the investment construction project.

Table 3: Recapitulation of economic results RBO.

\begin{tabular}{|c|c|c|c|c|c|}
\hline \multirow{2}{*}{ Variants } & \multicolumn{5}{|c|}{ Economic indicators } \\
\cline { 2 - 6 } & $\begin{array}{c}\text { Total capital } \\
\text { expenditure } \\
\text { [thousands } € \text { ] }\end{array}$ & $\begin{array}{c}\text { Economic time } \\
\text { of repayment } \\
\text { investments, } \\
\text { PA } \\
\text { [year] }\end{array}$ & $\begin{array}{c}\text { Economic } \\
\text { internal rate of } \\
\text { return [\%] }\end{array}$ & $\begin{array}{c}\text { Economic net } \\
\text { present value, } \\
\text { NPV } \\
\text { [thousands } € \text { ] }\end{array}$ & $\begin{array}{c}\text { Economic } \\
\text { benefit - cost } \\
\text { ratio, } \\
\text { BCR }\end{array}$ \\
\hline Variant Nr.1 & $10,562.16$ & 2026 & 16.00 & $24,804.55$ & 3.348 \\
\hline Variant Nr.2 & $11,096.15$ & 2026 & 16.13 & $25,082.19$ & 3.260 \\
\hline
\end{tabular}

\section{Conclusions}

The RMO project significantly contributes in its technical solution for both methods to increase in quality of transport, safety and travel speed of users of a bridge.

In view of mentioned economic results we can recommend both options as appropriate for their next project preparation. Those economic results are mutually insignificant different in all economic indicators.

Risks of variant Nr. 1, however, are significantly higher because of climate conditions in the area where the building is quite difficult to implement, which may increase disproportionately claims to comply the quality deadlines of construction and putting the construction into operation.

Contrariwise, Variant Nr. 2 requires in terms of construction site much less power and thus demands to ensure the quality and construction deadlines and has additional albeit slightly, still better economic result.

\section{Acknowledgement}

„This work was supported by the Slovak Research and Development Agency under the contract No. APVV-0106-11“.

This contribution is the result of the project implementation: "Support of Research and Development for Centre of Excellence in Transport Engineering" (ITMS: 26220120031) supported by the Research \& Development Operational Programme funded by the European Regional Development Fund.

\section{References}

[1] Guide to the cost-benefit analysis of investment projects in the transport version 2.1. Ministry DVRR SR, 2011.

[2] Working paper 4: Manual methodology for the development of cost-benefit analysis. European Commission, Directorate - General for Regional Policy, 2007. Available at: http://www.edis.sk/ekes/wd4_cost_sk.pdf.

[3] Act No.254 / 1998 Coll. public works, as amended by Act no. 260/2007 Coll.

[4] Decree 83/2008 Coll. Ministry DVRR SR implementing Act. 254/1998 Coll. public works, as amended by Act no. 26/2007 Coll.

[5] Technical Regulation: Principles for evaluation of investment construction projects. Road and Motorway Directorate of the Czech Republic, Prague, 2010.

[6] VALUCH, M.: The economic effects of the cost of the client. Valuation of construction work (In Slovak). ÚSE Bratislava, 2012. s. 71-78. ISBN 978-80-970019-0-2. 
[7] VALUCH, M. - REMIŠOVÁ, E. - REMEK, L'.: The effectiveness of the investment construction project (In Slovak). Scientific and technical journal Civil and Environmental Engineering. ISSN 1336-5835, 2010, Vol. 6, no. 2, p. 87-93.

[8] VALUCH, M. - REMIŠOVÁ, E.: Economic report on the project: Reconstruction of the bridge n.208 in Čadca (In Slovak). University of FCE, $2014^{\text {th }}$. 